\title{
Da Cena Independente às Gravadoras: A Dinâmica do Mercado Musical Brasileiro no Século XXI
}

\section{Giovane Gonelli Agapito*}

\section{Resumo}

Um sóbrio estudo sobre a dinâmica do mercado musical brasileiro a partir do uso das novas redes sociais, analisando as diferenças e semelhanças entre bandas underground ${ }^{1}$ e mainstream ${ }^{2}$ no panorama tecnológico no qual vivemos.

\section{Palavras-chave}

Mercado Musical Brasileiro, Redes Sociais, Internet.

\section{Introdução}

O mundo como conhecemos mudou demasiadamente nas últimas décadas, principalmente em decorrência do avanço da tecnologia no âmbito social. O aprimoramento das novas ferramentas digitais - redes sociais, sites de compartilhamento de vídeo, de streaming, financiamento coletivo, entre outros - ajudou consideravelmente o mercado musical independente brasileiro a adquirir uma atmosfera mais profissional e autônoma com bandas que, pelo menos visualmente e dentro da web, mostram ser tão bem preparadas como as oriundas das grandes gravadoras.

Com a devida ciência desse panorama, um sóbrio estudo sobre o tema foi realizado, buscando entender esse fenômeno tão recente, mas ao mesmo tempo essencial para a indústria fonográfica, enfatizando alguns aspectos como a diminuição gradual das prensagens de discos em detrimento de sites de streaming e compras digitais, a questão da pirataria musical; entre outros.

\section{Resultados e Discussão}

Após analisar os dados e abordagens midiáticas, é evidente que as preocupações estéticas e musicais andam lado-a-lado. Atualizações constantes nas redes sociais, fotos quase sempre tiradas por um fotógrafo contratado e o intuito das bandas de passar uma imagem de que ela se encontra sempre "em movimento", trabalhando e com muitos afazeres são apenas alguns dos exemplos, ainda que não sejam novidades. Redes sociais mais antigas como o Fotolog (2003) e Orkut (2004) já mostravam sinais claros dessa estratégia.

Foi, também, em meados dos anos 2000 que a plataforma Trama Virtual mostrava como era vender música digitalmente (e legalmente) nos primórdios da internet. Serviço que hoje é feito com mais fluidez via streaming $^{3}$ pelo Spotify, Deezer, entre outros. O PalcoMP3 e o MelodyBox também foram serviços que tentaram reproduzir o mesmo sucesso da Trama, mas foram ofuscados pelo brilho do MySpace, o qual começou a ter fama em 2005 e permaneceu no topo até poucos anos atrás. Musicalmente, seu uso era parecido com as redes sociais mais recentes (Facebook e Orkut, por exemplo), com uma página criada para o artista, um player de suas músicas, informações, fotos, vídeos: tudo ao alcance do usuário.

Analisando as 8 bandas escolhidas no início desses estudos, é evidente que o uso das redes sociais contribui muito, mas não é autossuficiente. Os contatos externos são essenciais para a manutenção da estrutura da banda, seja por um design (para manter a boa estética na web), assim como assessoria de imprensa, booker ${ }^{4}$ ou empresário. Talvez essa seja a principal diferença entre os mundos do underground e mainstream: no $1^{\circ}$ caso, dificilmente tais profissionais acompanham as bandas, então tudo é feito pelos próprios integrantes. Apesar do intuito ser semelhante, o público atingido é infinitamente menor, embora algumas alternativas sejam válidas: a divulgação do conteúdo musical em blogs e sites de música não têm o mesmo alcance adquirido em revistas e programas de televisão - conseguidas com a ajuda de um empresário e uma assessoria, panorama praticamente impossível para bandas undergrounds -, mas é uma ótima alternativa.

Outro exemplo: o ato de entrar em contato com donos de casas noturnas e a própria banda organizar seu próprio show é uma boa chance de divulgar seu material na ausência de um booker, por exemplo. As chances são infinitas.

\section{Conclusões}

A internet, mais do que nunca, tornou o mercado musical muito empreendedor, não importando o tamanho de sua banda. Facilidades de gravação, como estúdios caseiros e softwares profissionais de mixagem e masterização que facilitaram demasiadamente 0 trabalho de profissionais da área, também facilitaram os meios de se fazer música com qualidade. Porém, a mercantilização das redes sociais criou a falsa sensação de que o artista consegue ser autossuficiente utilizando a internet, mas essa frase está longe de ser verdade, se o intuito for ultrapassar a barreira do underground e chegar até o mainstream. Há muito o que ser discutido ainda, pois meus estudos foram pausados com 4 meses de pesquisa, ao invés dos 12 originalmente programados.

\section{Agradecimentos}

Agradeço humildemente ao Programa Institucional de Bolsas de Iniciação Científica e Tecnológica da UNICAMP (PIBIC), ao CNPq e ao SAE por viabilizarem minha pesquisa e me darem todo o apoio necessário.

\footnotetext{
${ }^{1}$ São as bandas independentes que não possuem contrato com gravadoras

2é o contato com os meios de comunicação, geralmente artistas que são administrados por grandes gravadoras.

3 forma de transmissão instantânea de dados de áudio e vídeo através de redes. ${ }^{4}$ uma pessoa ou empresa que organiza toda a agenda de eventos de determinado artista ou empresa.
} 